Hydrology and Earth System Sciences, 9(4), 333-346 (2005) C EGU

\title{
Coupling meteorological and hydrological models for flood forecasting
}

\author{
Jens Bartholmes ${ }^{1}$ and Ezio Todini² \\ ${ }^{1}$ European Commission - DG Joint Research Centre, Institue for Environment and Sustainability, Via E, Fermi, TP 261, 21020, Ispra (Va), Italy \\ ${ }^{2}$ Department of Geo-Environmental Sciences, University of Bologna, Via Zamboni 67, 40126, Bologna, Italy
}

Email for corresponding author: jens.bartholmes@jrc.it

\begin{abstract}
This paper deals with the problem of analysing the coupling of meteorological meso-scale quantitative precipitation forecasts with distributed rainfall-runoff models to extend the forecasting horizon. Traditionally, semi-distributed rainfall-runoff models have been used for real time flood forecasting. More recently, increased computer capabilities allow the utilisation of distributed hydrological models with mesh sizes from tenths of metres to a few kilometres. On the other hand, meteorological models, providing the quantitative precipitation forecast, tend to produce average values on meshes ranging from slightly less than 10 to 200 kilometres. Therefore, to improve the quality of flood forecasts, the effects of coupling the meteorological and the hydrological models at different scales were analysed. A distributed hydrological model (TOPKAPI) was developed and calibrated using a $1 \times 1 \mathrm{~km}$ mesh for the case of the river Po closed at Ponte Spessa (catchment area $c .37000$ $\mathrm{km}^{2}$ ). The model was then coupled with several other European meteorological models ranging from the Limited Area Models (provided by DMI and DWD) with resolutions from $0.0625^{\circ} * 0.0625^{\circ}$, to the ECMWF ensemble predictions with a resolution of $1.85^{\circ *} 1.85^{\circ}$. Interesting results, describing the coupled model behaviour, are available for a meteorological extreme event in Northern Italy (Nov. 1994). The results demonstrate the poor reliability of the quantitative precipitation forecasts produced by meteorological models presently available; this is not resolved using the Ensemble Forecasting technique, when compared with results obtainable with measured rainfall.
\end{abstract}

Keywords: Flood Forecasting, rainfall-runoff, hydrological model, Coupling, numerical weather prediction, quantitative precipitation forecast (QPF)

\section{Introduction}

In river flood forecasting, different approaches associated with different levels of uncertainty and forecasting lead time are possible. Forecasts of river discharges are often made using a purely hydraulic approach, i.e. the outflow hydrograph of a stream is derived using equations of flow. This approach is the most precise available, with the lowest associated forecast uncertainty, but forecasting lead time is limited to the travel time of water in the channel. To extend the forecasting horizon it becomes necessary to include the process prior to river routing, explicitly runoff generation, in the forecasting procedure. This can be done with a variety of hydrological rainfall-runoff models. Complex physicallybased distributed models like the SHE (Abbot et al., $1986 a, b, c$ ) feature a very accurate description of the physics involved but traditionally require a large amount of input data. Alternatively, lumped models like the HBV (Bergstrom, 1976) or the Xinanjiang Model (Zhao and Liu, 1995) and semi-distributed models like the ARNO model (Todini, 1996) or the HEC (Feldman, 1981) are modelling (sub-) basin response, ignoring spatial variability. Similarly, the TOPMODEL, a physically-based lumped model whose features are derived from distributed geomorphological information, is more easy to apply than SHE, as the amount of data required and CPU time results are significantly smaller. For a complete review of hydrological models see Singh (2002).

As forcing of rainfall-runoff models, observations in 'real time' from rain gauges, weather radar, satellite observations (or combinations of those) can be used and thus the flood forecasting horizon can be extended to the time it takes the flood producing part of precipitation to cover the distance 
between the ground impact location and the river channel at the outlet.

For water authorities it can be useful to extend the forecasting horizon further in order to implement their emergency plans for downstream areas effectively. This additional gain in lead time can be achieved only by including precipitation information ahead of its occurrence, for instance by using quantitative precipitation forecasts (QPF) of numerical weather prediction systems. With this methodology, national water authorities are normally able to provide flood warnings between one and four days in advance.

The 5th framework EU R\&D project European Flood Forecasting System (EFFS) - of which the results for the river Po (Northern Italy) will be presented here - studies the feasibility of a system with an even further extended forecasting horizon. This extension is possible by taking advantage of up-to-date hydrological rainfall-runoff models in combination with the currently available medium-range weather forecasts with up to 10 days of lead time (Bates et al., 2003). Naturally, increase in lead time is related to higher uncertainty in the flood forecast but, with enough warning time, effective adaptation of emergency management procedures can also be made with a less than perfect forecast.

\section{Hydrological rainfall-runoff model description}

In this study the physically-based distributed rainfall-runoff model TOPKAPI (TOPographic Kinematic APproximation and Integration) will be used (Todini, 1995). It evolved from a critical analysis of the ARNO model and TOPMODEL. One of the general improvements made in this model is the ability of TOPKAPI to maintain the physical meaning of its parameters across scales, a property that does not hold for TOPMODEL when passing from hillslope scale to bigger scales (Franchini et al., 1996).

As the acronym suggests, the basic idea of the TOPKAPI model is to combine TOPographic basin information with the Kinematic wave APproximation and its Integration in space. The model consists of five main modules representing the soil, the surface, the drainage network, the evaporation and the snow component. The first three are in the form of 'structurally-similar' non-linear reservoir equations. They are obtained by lumping the kinematic wave assumption at the scale of the processing units, i.e. the grid cells that are defined through the underlying DEM which serves to describe the topography of the basin. The evapotranspiration component can be given as direct input data or internally calculated using the radiation method (Doorenbos et al., 1984) taking temperature as variable input. The snow component is also simulated as being independent of temperature and both are borrowed from the ARNO model (Todini, 1996).

The TOPKAPI model is based on six fundamental assumptions :

- Precipitation is constant over the integration domain, i.e. the single DEM cell;

- All precipitation reaching the soil infiltrates, unless the soil in this particular cell is already saturated (Dunne, 1978);

- The slope of the water table coincides with the ground slope. If smaller than $0.01 \%$, it is set to $0.01 \%$;

- Local transmissivity, like local horizontal flow, depends on the integral of the water content profile in the vertical;

- In the soil surface layer the saturated hydraulic conductivity is constant with depth and much larger than in deeper layers;

- During the transition phase the variation of water content in time is constant in space.

\section{THE SUBSURFACE COMPONENT}

At the point scale, the fundamental equations that represent the phenomenon are the equation of continuity (Eqn. 1) and an equation of flow (represented in an approximated form in Eqn. 2 (Todini and Ciarapica, 2001)).

$$
\begin{aligned}
& \left(\vartheta_{s}-\vartheta_{r}\right) L \frac{\partial \widetilde{\Theta}}{\partial t}+\frac{\partial q}{\partial x}=p \\
& q=\tan (\beta) T(\widetilde{\Theta})=\tan (\beta) k_{s} L \tilde{\Theta}^{\alpha}
\end{aligned}
$$

in which: $\widetilde{\Theta}=\frac{1}{L} \int_{0}^{L} \widetilde{\vartheta}(z) d z$ average soil moisture content along the

$\tilde{\vartheta}=\frac{\vartheta-\vartheta_{r}}{\vartheta_{s}-\vartheta_{r}}$ reduced soil moisture content

$\vartheta_{r} \quad$ residual soil moisture content (due to capillarity, gravity)

$\vartheta_{s} \quad$ saturated soil moisture content

$\vartheta \quad$ water content in the soil

$L \quad$ thickness of surface soil layer in $\mathrm{m}$

$z \quad$ vertical direction

$x \quad$ main direction of flow along a cell

$t$ time

$q$ horizontal flow in the soil. Due to drainage; discharge per unit of width in $\mathrm{m}^{2} \mathrm{~s}^{-1}$

$p \quad$ precipitation intensity in $\mathrm{m} \mathrm{s}^{-1}$

$k_{s} \quad$ saturated hydraulic conductivity in $\mathrm{m} \mathrm{s}^{-1}$ 
parameter which depends on soil characteristics (Todini, 1995)

$\tan (\beta)$ surface slope, assumed to coincide with the water table slope

The actual total water content in the soil along the vertical axis can be expressed by :

$$
\eta=\left(\vartheta_{s}-\vartheta_{r}\right) L \tilde{\Theta}
$$

where $\eta$ has the unit [m]. With this substitution (1) and (2) become :

$$
\begin{aligned}
& \frac{\partial \eta}{\partial t}=p-\frac{\partial q}{\partial x}\left[\mathrm{~m} \mathrm{~s}^{-1}\right] \\
& q=\frac{L k_{s} \tan (\beta)}{\left(\vartheta_{s}-\vartheta_{r}\right)^{\alpha} L^{\alpha}} \eta^{\alpha}=C \eta^{\alpha}\left[\mathrm{m}^{2} \mathrm{~s}^{-1}\right]
\end{aligned}
$$

where $\mathrm{C}$ is expressed by:

$$
C=\frac{L k_{s} \tan (\beta)}{\left(\vartheta_{s}-\vartheta_{r}\right)^{\alpha} L^{\alpha}}\left[\mathrm{m}^{2-a} \mathrm{~s}^{-1}\right]
$$

The term $C$ represents a 'local conductivity coefficient' . It incorporates the effects of the cell specific soil parameters for hydraulic conductivity and slope to which it is directly proportional, and storage capacity to which it is inversely proportional (Liu and Todini, 2002).

Merging Eqns. (3)-(6) leads to the final kinematic equation for the subsurface component :

$$
\frac{\partial \eta}{\partial t}=p-\frac{\partial\left(C \eta^{\alpha}\right)}{\partial x}
$$

Integrating Eqn. (7) in the soil over the $i^{\text {th }}$ DEM cell which space dimension is $\mathrm{X}$ in metres gives:

$$
\frac{\partial v_{s_{i}}}{\partial t}=p X-\left(C_{s_{i}} \eta_{s_{i}}^{\alpha_{s}}-C_{s_{i-1}} \eta_{s_{i-1}}^{\alpha_{s}}\right)
$$

where $v_{s_{i}}$ is the volume per unit of width stored in the $i^{\text {th }}$ cell in $\mathrm{m}^{2}$, while the last term in Eqn. (8) represents the inflow and outflow balance.

Similarly to the SHE, in the TOPKAPI model water moves down-slope in a four-direction, tree-shaped network of grid cells until it reaches the outlet of the basin. Assuming that in each cell the variation of the vertical water content $\eta_{s_{i}}$ along the cell is negligible, the volume of water stored in each cell (per unit width) can be related to the total water content $\eta_{s_{i}}$ - equivalent to the free water volume in depth - by means of the following simple expression:

$$
v_{s_{i}}=X \eta_{s_{i}}
$$

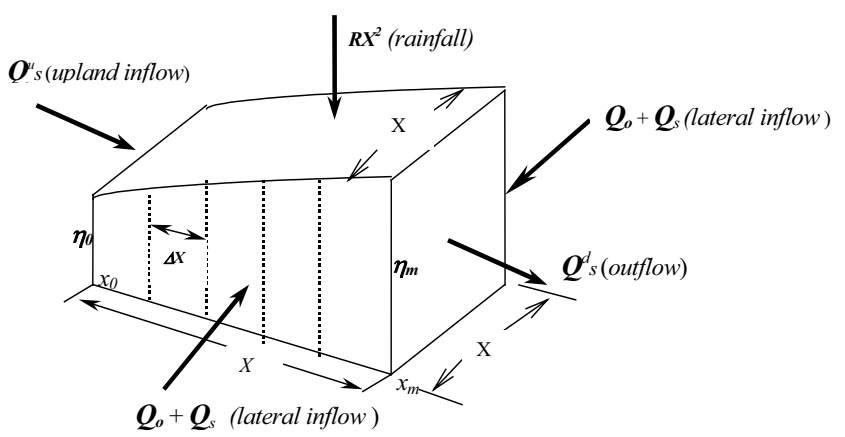

Fig. 1. Soil module input and output to a generic cell (taken from Liu, 2002)

After substituting $\eta_{s_{i}}$ in Eqn. (8), a non-linear reservoir equation can be written for a generic cell, given the total inflow to the cell:

$$
\frac{\partial V_{s_{i}}}{\partial t}=\left(p_{i} X^{2}+Q_{o_{i}}^{u}+Q_{s_{i}}^{u}\right)-\frac{C_{s_{i}} X}{X^{2 \alpha_{s}}} V_{s_{i}}^{\alpha_{s}}
$$

where $V_{s_{i}}$ is the volume stored in the $i^{\text {th }}$ cell in $m^{3}, Q_{o_{i}}^{u}$ is the discharge entering the active cell $i$ as overland flow from the upstream contributing area $\left(m^{3} s^{-1}\right)$, and $Q_{s_{i}}^{u}$ is the discharge entering the active cell (see Fig. 1) as subsurface flow from the upstream contributing area in $m^{3} s^{-1}$.

\section{THE CHANNEL AND SURFACE COMPONENT}

Following an analogue procedure for the overland flow assuming constant surface water depth - and integrating over the longitudinal dimension, results in the following non-linear reservoir equation for the $i^{\text {th }}$ cell:

$$
\frac{\partial V_{o_{i}}}{\partial t}=r_{o_{i}} X^{2}-\frac{C_{o_{i}} X}{X^{2 \alpha_{o}}} V_{o_{i}}^{\alpha_{o}}
$$

where $V_{o_{i}}$ is the volume of the water on the surface in the $i^{\text {th }}$ cell (see Fig. 2) in $m^{3}, r_{o}$ is the saturation excess resulting from the solution of the soil water balance Eqn. (10).

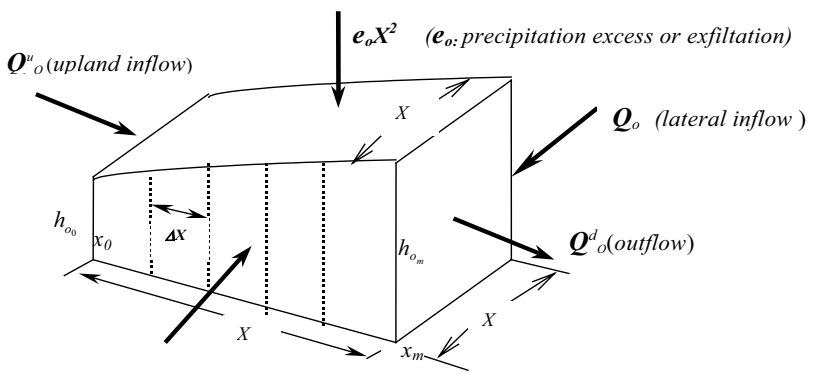

$\boldsymbol{Q}_{o}$ (lateral inflow)

Fig. 2. Surface module input and output to a generic cell (taken from Liu, 2002) 
For the tree-shaped channel network with rectangular cross sections - and increasing width as a function of the area drained - the resulting non-linear reservoir equation can be written for a generic channel reach as:

$$
\frac{\partial V_{c_{i}}}{\partial t}=\left(r_{c_{i}} X W_{i}+Q_{c_{i}}^{u}\right)-\frac{C_{c_{i}} W_{i}}{\left(X W_{i}\right)^{\alpha_{c}}} V_{c_{i}}^{\alpha_{c}}
$$

where $V_{c_{i}}$ is the volume of water stored in the $i^{\text {th }}$ channel reach in $m^{3}, r_{c}$ is the lateral drainage input, $W_{i}$ is the width of the $i^{\text {th }}$ rectangular channel reach, $Q_{c_{i}}^{u}$ is the inflow discharge from the upstream reaches in $\mathrm{m}^{3} \mathrm{~s}^{-1}$.

A more detailed description of the model can be consulted in Liu and Todini (2002).

\section{Basin description}

The Po river basin is situated in northern Italy and covers an area of $73000 \mathrm{~km}^{2}$. The Po river is the largest Italian river and 15 million people live within its reach (population densities up to 1500 inhabitants $\mathrm{km}^{-2}$ ). It has a total length of $650 \mathrm{~km}$ stretching from its headwaters, at $2000 \mathrm{~m}$ elevation, in the Piedmont region close to France, through all of northern Italy to the Adriatic sea where it has its delta near the city of Ravenna (Fig. 3).

The present work is focused on the upper portion of the basin (37 $000 \mathrm{~km}^{2}$ draining area) upstream of the hydrometric station of Ponte Spessa (Fig. 4). The most severe meteorological events take place in this region, with peak discharges significantly higher than in the lower reaches of the river. For instance, the 1994 flood resulted in a discharge peak of ca. $11.990 \mathrm{~m}^{3} \mathrm{~s}^{-1}$ at Ponte Spessa, whereas the peak discharge at the station of Ponte Lagoscuro

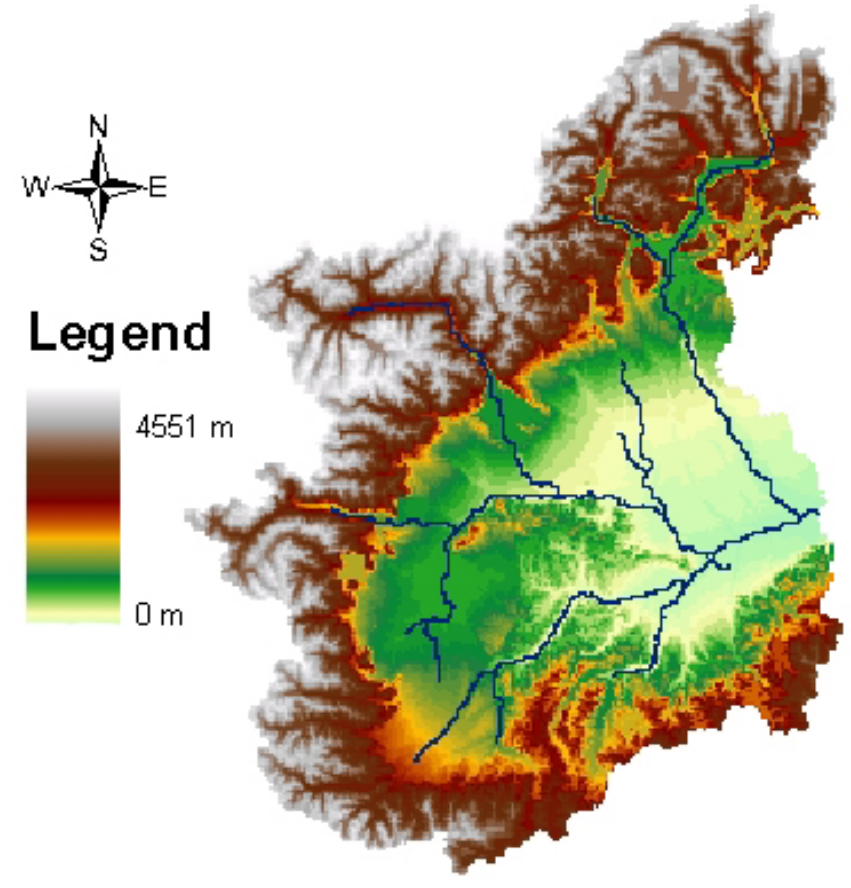

Fig. 4. DEM of the study region

close to the Adriatic sea, was ca. $8700 \mathrm{~m}^{3} \mathrm{~s}^{-1}$ for the same event.

The DEM, the soil type map and the soil use map were obtained from public geological databases (USGS, NOAA). The TOPKAPI soil type parameter values were calculated referring to soil type specifications from NOAA and FAO (websites) whereas land-use parameters and river channel parameters were taken from the literature (Chow, 1988; Dingman, 2002).

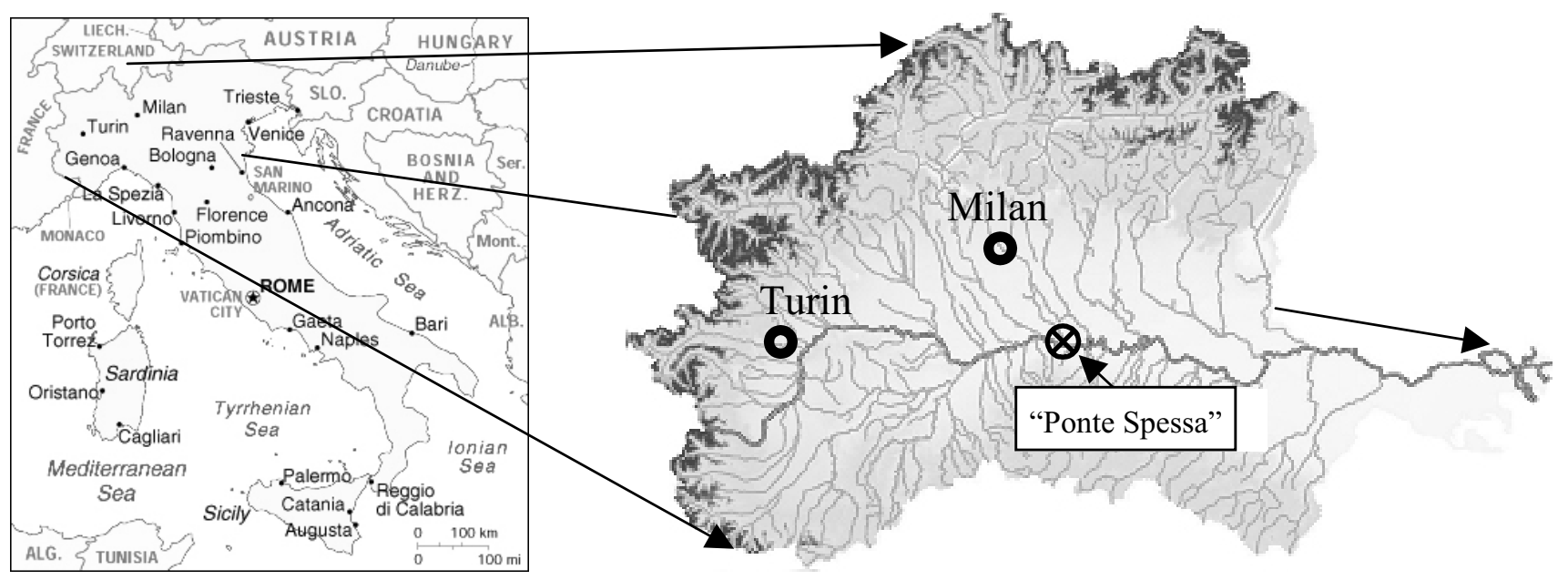

Fig. 3. Study region. The river Po basin closed at the hydrometric station Ponte Spessa. 
The available meteorological data consist of observations for the years 1994 to 2000 from 74 rain gauges and 61 temperature stations. These data have a temporal resolution of one hour and are homogeneously distributed in space. Spatial fields were derived via the Thiessen polygon method. The streamflow records were available only at the hydrometric station Ponte Spessa (Fig. 3).

\section{Model calibration and evaluation}

The model was calibrated using a 3-month period from September to November 1994. This period includes a flood event with a return period of the order of 100 years (Brath, 1995; Luino, 1999) which was one of the major recent European flood events chosen to be investigated within the EFFS project. No calibration in the usual sense of a curve fitting process was undertaken in this study. The tuning of parameters was done globally by applying multiplication factors uniformly to the entire parameter grid map that maintained the relations between the parameter values of the several classifications of soil types constant. This preserved the physical meaning as far as possible and strongly reduced the calibration work (Bindlish and Barros, 2000).
The quality of the calibration results was expressed through several skill estimators: Nash and Sutcliffe (1970), Chiew and MacMahon (1994), Willmott (1981) and a volume control (for details see Appendix A). All these estimators have the value 1.0 if observed and simulated hydrographs match $100 \%$ and get smaller the more the hydrographs differ. To visualise the simulation results in a concentrated, easily accessible way, Fig. 5, showing the calibration results, comprises four windows. The upper one shows the observed versus the simulated hydrograph, the lower left is a dotty plot of observed versus simulated discharge, the lower middle graphic reports various skill factors and the lower right the simulated discharge input and output of the reservoir Lake Maggiore $\left(212 \mathrm{~km}^{2}\right)$.

Model evaluation was carried out for the period 1994 to 2000. For this period, coefficient values were: Nash-Sutcliffe 0.87, Chiew 0.78, Willmott 0.98 and Volume control 0.98 . For the evaluation period the residuals between observed and simulated discharge had a standard deviation of $277 \mathrm{~m}^{3} \mathrm{~s}^{-1}$ and almost no bias with a mean of $21 \mathrm{~m}^{3} \mathrm{~s}^{-1}$ and a median of $9 \mathrm{~m}^{3} \mathrm{~s}^{-1}$. The overall correlation between observed and simulated discharge for the evaluation period was 0.94 .
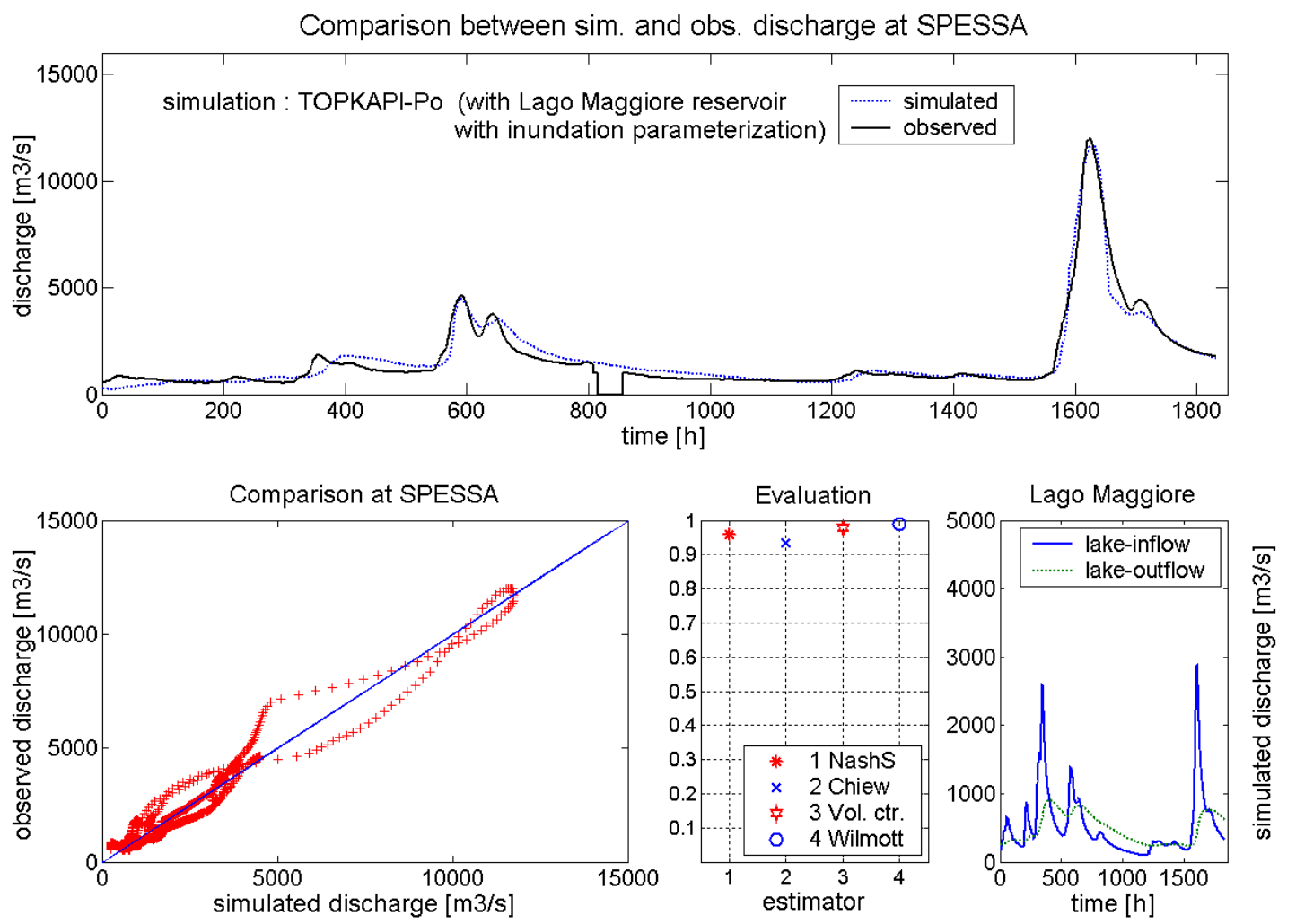

Fig. 5. Model performance for the period of Sept.1994 to Dec.1994 


\section{Meteorological data}

The quantitative precipitation forecasts (QPF) used in the EFFS project cover the range from very coarse horizontal resolution Global Models (GM) to high resolution Limited Area Models (LAM). The GM have forecasting lead times of up to 10 days ahead, whereas the LAM are limited to 2 and 3 days lead time. Deterministic forecasts as well as 'ensemble prediction' approaches have been applied in this study. General characteristics of the numerical weather prediction systems are:

\section{ECMWF forecasts}

The European Centre for Medium Range Weather Forecast (ECMWF) provided three different GM forecast variations: A deterministic forecast and two different 'ensemble predictions'. The deterministic forecast has a spatial resolution of $0.5^{\circ} * 0.5^{\circ}$ (grids in Po basin: c. $40 * 55 \mathrm{~km}$ ) and values for temperature and accumulated precipitation are given every 6 hours for the first 5 days and every 12 hours from day 6 to 10 .

The new ECMWF Ensemble Prediction System (EPS) (Molteni et al., 1996) provides an ensemble of 50 perturbed members and a control forecast at a spatial resolution of $0.75^{\circ} * 0.75^{\circ}$ (grids in Po basin: c. $85^{*} 125 \mathrm{~km}$ ) with temperature and accumulated precipitation values every 12 hours. The old EPS features 32 members with a spatial resolution of $1.875^{\circ} 1.875^{\circ}$ (grids in Po basin: c. $145^{*} 215 \mathrm{~km}$ ) and a temporal resolution of 12 hours. The EPS perturbation technique is based on a singular vector analysis and tries to identify the most unstable atmospheric locations where already small uncertainties in the initial conditions would most affect the 48-hour forecast (Buizza and Palmer, 1995). All ECMWF forecast used in the EFFS project have a forecasting lead time of 10 days.

\section{DWD forecasts}

The German Weather Service (Deutscher Wetter Dienst or DWD) provided quantitative precipitation forecasts from its GM as well as from its LAM, the so-called 'Lokal Model' (Heise et al., 2000). The GM has a spatial resolution of $0.75^{\circ} * 0.75^{\circ}$ (grids in Po basin: c. $55^{*} 85 \mathrm{~km}$ ), a temporal resolution of 6 hours and a forecasting lead time of 156 hours (6.5 days). The DWD LM has a high spatial resolution of

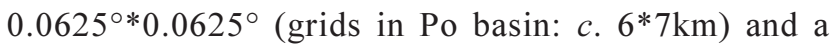
temporal resolution of 1 hour with a forecasting lead time of 48 hours. The DWD LM is nested in the DWD GM, i.e. the LM boundary conditions at the edges of the domain are provided by the GM. The DWD LM is the only numerical weather prediction model in the EFFS project that uses a non-hydrostatic representation of the atmosphere.

\section{DMI forecasts}

The Danish Hydrological Institute (DMI) provided forecasts from its version of the High Resolution Local Area Model (HIRLAM) (Kaellen, 1996). The forecasts have a spatial resolution of $0.1^{\circ *} 0.1^{\circ}$ (grids in Po basin: $c .11^{*} 11 \mathrm{~km}$ ) and provide accumulated precipitation estimates for every hour with a lead time of 72 hours. The version used for EFFS features a two-step, one-way nesting, i.e. the lateral boundary conditions of a $0.3^{\circ}$ resolution LAM are initialised and updated every 6 hours with ECMWF GM data and at the same time a second LAM with a resolution of $0.1^{\circ}$ is initialised and updated hourly at its boundary by the $0.3^{\circ}$ model (Sattler, 2002).

In the context of the EFFS project, DMI also provided data from an experimental 'mini ensemble' consisting of five members nested in ECMWF EPS members and of four members with different small scale parameterisation schemes (Sattler and Feddersen, 2003).

\section{Extraction of meteo data}

The Numerical Weather Prediction systems provided Quantitative Precipitation Forecasts (QPF) that give values of accumulated precipitation for every (model specific) time step $\Delta \mathrm{t}_{\text {meteo }}$. The meteorological institutes used the binary GRIB format to store these large amounts of data in a storage efficient way. To be used with the hydrological model, the data have to be extracted, filtered and transformed into ASCII format. The ASCII data were then introduced into the TOPKAPI model treating the meteorological grid cells like Thiessen polygons and for $\Delta \mathrm{t}_{\text {meteo }}>1$ hour $\left(=\Delta \mathrm{t}_{\text {hydro }}\right)$ the accumulated precipitation was equally distributed in time.

\section{Flood forecasting}

In autumn 1994, a disastrous flood occurred in north-western Italy in the Piedmont region. Heavy rainfall episodes lasted from the 3 rd to 6th of November, with local accumulated rainfall of over $300 \mathrm{~mm}$ in 36 hours (Buzzi et al., 1995). The severe meteorological conditions were determined by strong southerly airstreams that brought moist and highly unstable air to the region. The eastward propagation of the cold front associated with the cyclonic circulation was slowed down by a blocking situation. The precipitation was further intensified by mesoscale dynamic and thermodynamic forcings superimposed on the synoptic lowpressure pattern (Cassardo et al., 2002).

Caused by the heavy persistent precipitation, a peak discharge of $11.990 \mathrm{~m}^{3} \mathrm{~s}^{-1}$ at $5 \mathrm{pm}$ on 7 th November 1994 was observed in the river Po at Ponte Spessa. This 100-year flood was taken as a case study for the EFFS project and will be discussed here. Meteorological hindcasts for the time 
around this event were provided by the EFFS partners and the rainfall-runoff model TOPKAPI was forced with the different kinds of hindcasts.

The ECMWF deterministic hindcasts were applied starting 29th October 1994 up to 6th November 1994. Already on the 29.10.1994 (nine days before the observed flood peak) the onset as well as a peak of $10.200 \mathrm{~m}^{3} \mathrm{~s}^{-1}$ are predicted at the same time as the observed. However, the hindcast starting the following day does not capture the event and simulated discharges remain under $2000 \mathrm{~m}^{3} \mathrm{~s}^{-1}$. From 31.10.1994 to 06.11.1994. the simulations done with the ECMWF deterministic hindcasts all consistently indicate an extreme flood event around 07.11.1994. Discharge predictions after 31.10 .1994 are never lower than $10.000 \mathrm{~m}^{3} \mathrm{~s}^{-1}$ and from 03.11 .1994 differ less than $15 \%$ from the observed peak. The predicted time of arrival of the peak is constantly less than 10 hours distant from the observed peak already from 01.11.1994. The sequence of simulations is shown in Fig. 6 .

The DWD GM deterministic hindcasts were available from the 01.11.1994. All six consecutive flood predictions indicate a flood event around 07.11.1994. The discharge peak of the event was underestimated and predictions are less than $10.000 \mathrm{~m}^{3} \mathrm{~s}^{-1}$ until 04.11.1994; however, the predicted event magnitude was steadily increasing and consistent. On 05.11.1994, the second, smaller peak was $100 \%$ over-predicted. The sequence of simulations is shown in Fig. 7.

From the DMI LM, deterministic hindcasts were available from 02.11.1994 to 05.11.1994. Again, there is a strong indication for a large flood but the magnitude is underestimated (Fig. 8).

Starting with 04.11.1994, the simulations with the DWD LM predicted the timing of the flood event with $\leq 10$ hours difference to the observed peak time (at lead times $\leq 3$ days), but due to strongly overestimated precipitation the resulting flood peak discharge was over-predicted by almost $100 \%$ (Fig. 9).

Next, the TOPKAPI was forced with ensemble predictions from the old ECMWF EPS. Due to the coarse resolution of these predictions the study area was covered by just four meteorological grid cells. As a result of the inherent strong spatial averaging of model orography and local rainfall intensities, the predicted precipitation intensities were not high enough to result in the simulation of a bigger flood event. Over the sequence of simulations (Fig. 10) from 28.10.1994 to 05.11 .1994 , only very few ensemble members predicted discharges greater than $4.000 \mathrm{~m}^{3} \mathrm{~s}^{-1}$ and the time of peak arrival was always too late.

The hindcasts from the new higher spatial resolution ECMWF EPS were available from 29.10.1994 to 03.11.1994. Like the ECMWF deterministic hindcast simulations, already on 29.10.1994 some of the ensemble members strongly indicated a 100-year flood event some 10 days in the future. However, in the sequence of simulations (Fig. 11), only one member (on 31.10.1994) predicts a discharge greater than the observed discharge, whereas all other members in all simulations stay on average way below it.

To give an overview of forecasting skill, the results of the predictions were summarised graphically (Fig. 12 to 15). The performance was expressed in the ability of the combination - of numerical weather prediction system with the hydrological model — to predict the magnitude of the discharge as well as the time of peak discharge. Figure 12 illustrates that the simulations using the DMI-LM as well as the DWD-GM both tend to underestimate the peak discharge but that forecasted discharge magnitude is steadily rising coming closer towards the event; on the other hand the DWD-LM strongly overestimates the event (up to $70 \%$ ) even two days before. The simulations based on the ECMWF deterministic predictions already indicate an event ( $40 \%$ of observed discharge) 11 days ahead but the predictions oscillate strongly from day to day until four days ahead of the event when predicted discharges differ by less than $15 \%$ from the observed value. The time of peak is predicted with a difference \pm 15 hours from six days ahead of the event (exception DWD-LM at four days lead time) (Fig. 13).

At 1 day of lag time all predictions concur because the rainfall-runoff model has a 30 -hour deterministic forecasting horizon in which the discharge prediction is almost completely derived from initial conditions which take into account only observed precipitation up to this point in time (Bartholmes et al., 2003).

The new ECMWF EPS generally under-predicted discharges (mean c. 50\% of observed value) and the standard deviation is large, whereas the old ECMWF EPS has a smaller standard deviation but discharges on average are predicted with only $20 \%$ of the observed value (Fig. 14). The time of peak is predicted well with small standard deviation $(<20$ hours up to 7 -day lag time $)$ by the new ECMWF EPS, while the old ECMWF EPS has a large standard deviation ( $>80$ hours) at lag times $>6$ days and predicts the peak constantly too late for lag times $<7$ days (Fig. 15). The statistics for the simulations with the old and new ECMWF EPS are summarised in Table 1.

A DMI LM mini ensemble was available only for the start date 03.11.1994. On average, the ensemble members derived from parameterisation perturbation predicted slightly higher discharges than the one based on ECMWF perturbed initial conditions, but none of them predicted discharges higher than $8000 \mathrm{~m}^{3} \mathrm{~s}^{-1}$ (Fig. 16). 
Jens Bartholmes and Ezio Todin
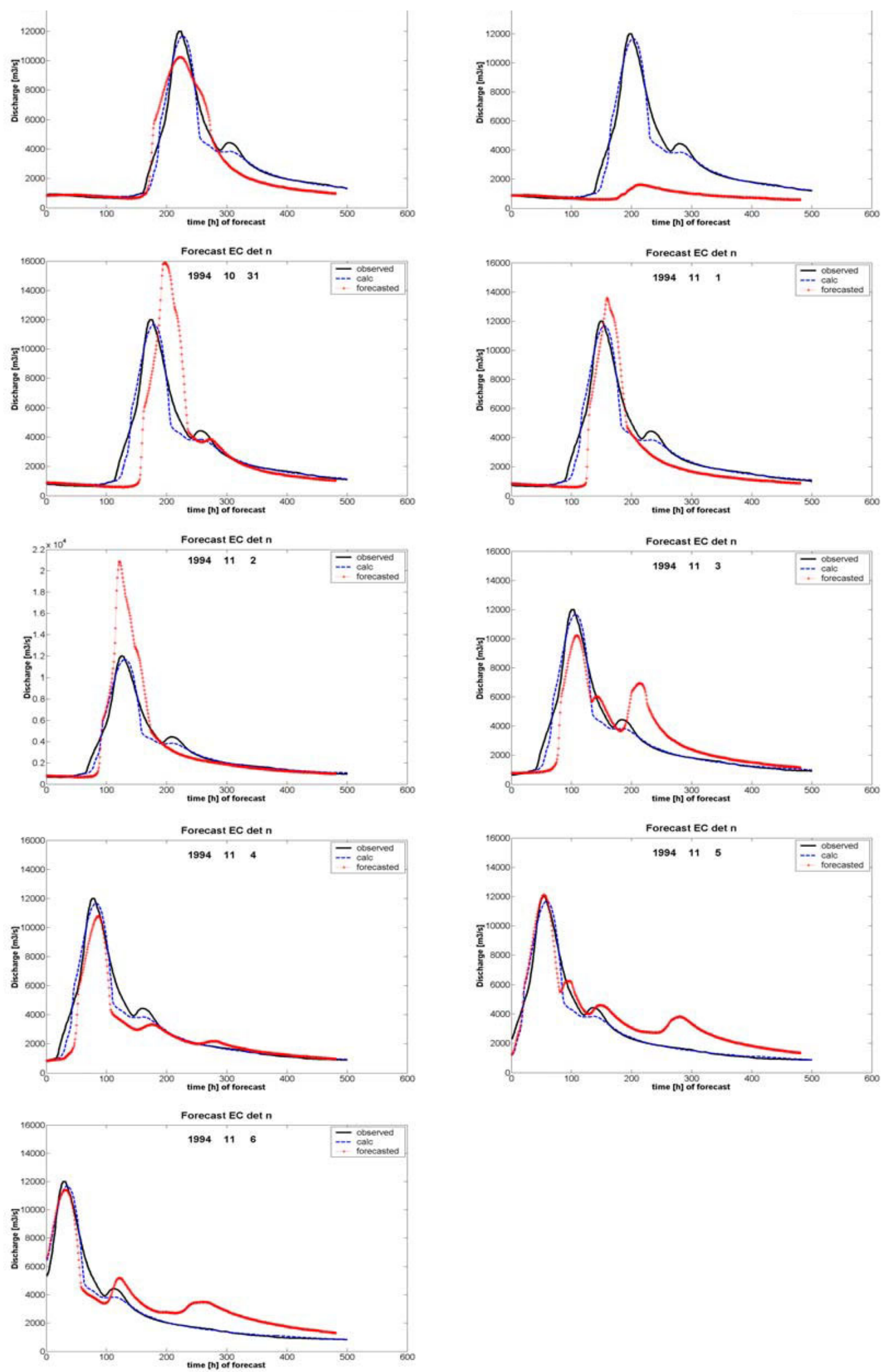

Fig. 6. Successive daily flood forecasts based upon the ECMWF deterministic hindcasts from 29.10.1994 to 06.11.1994 

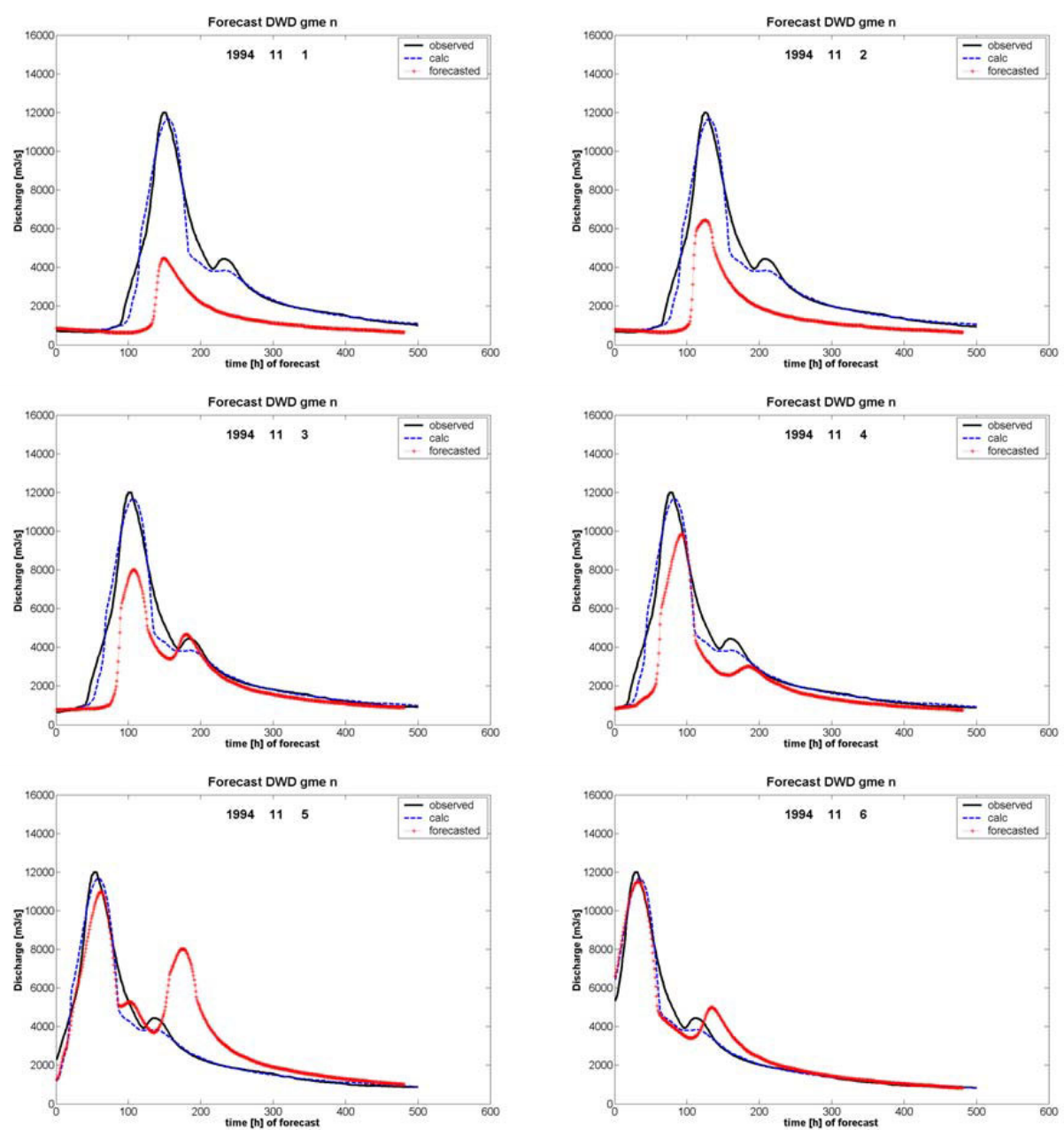

Fig. 7. Successive daily flood forecasts based upon the DWD GM deterministic hindcasts from 01.11.1994 to 06.11.1994
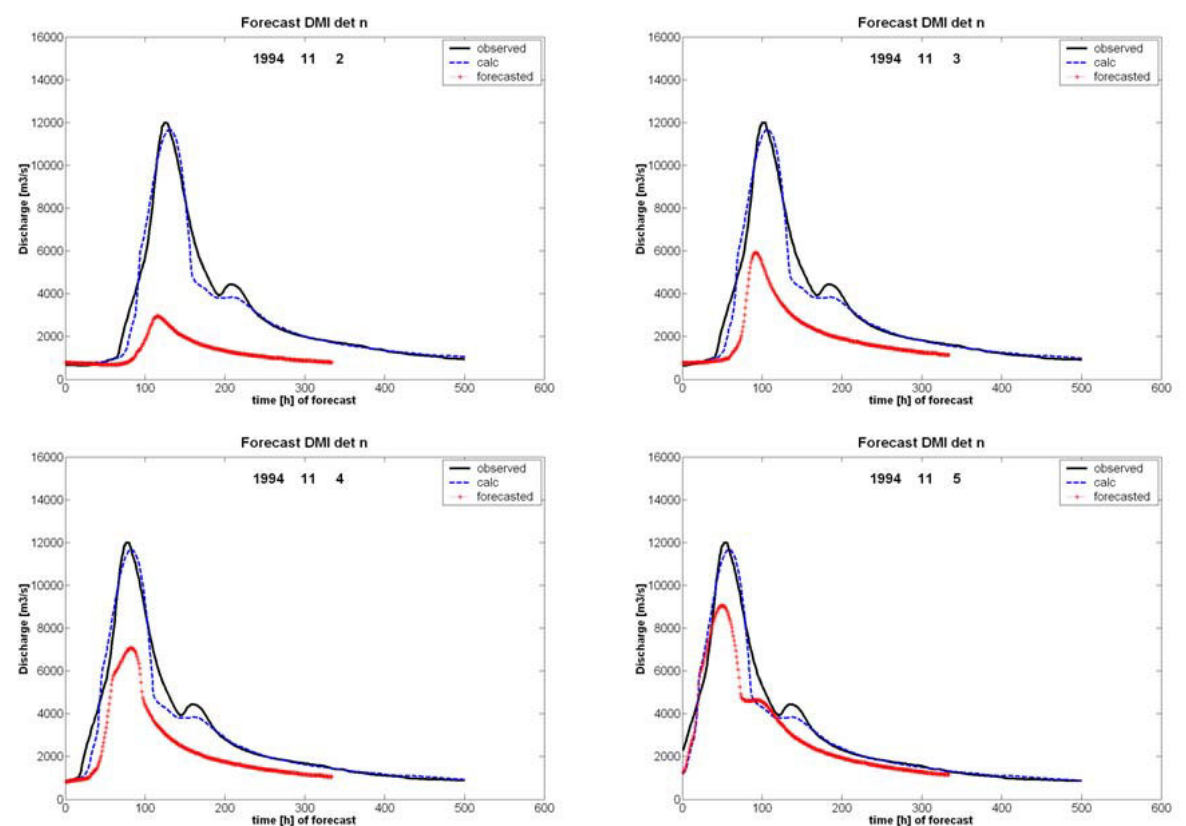

Fig. 8. Successive daily flood forecasts based upon the DMI LM deterministic hindcasts from 02.11.1994 to 05.11.1994 

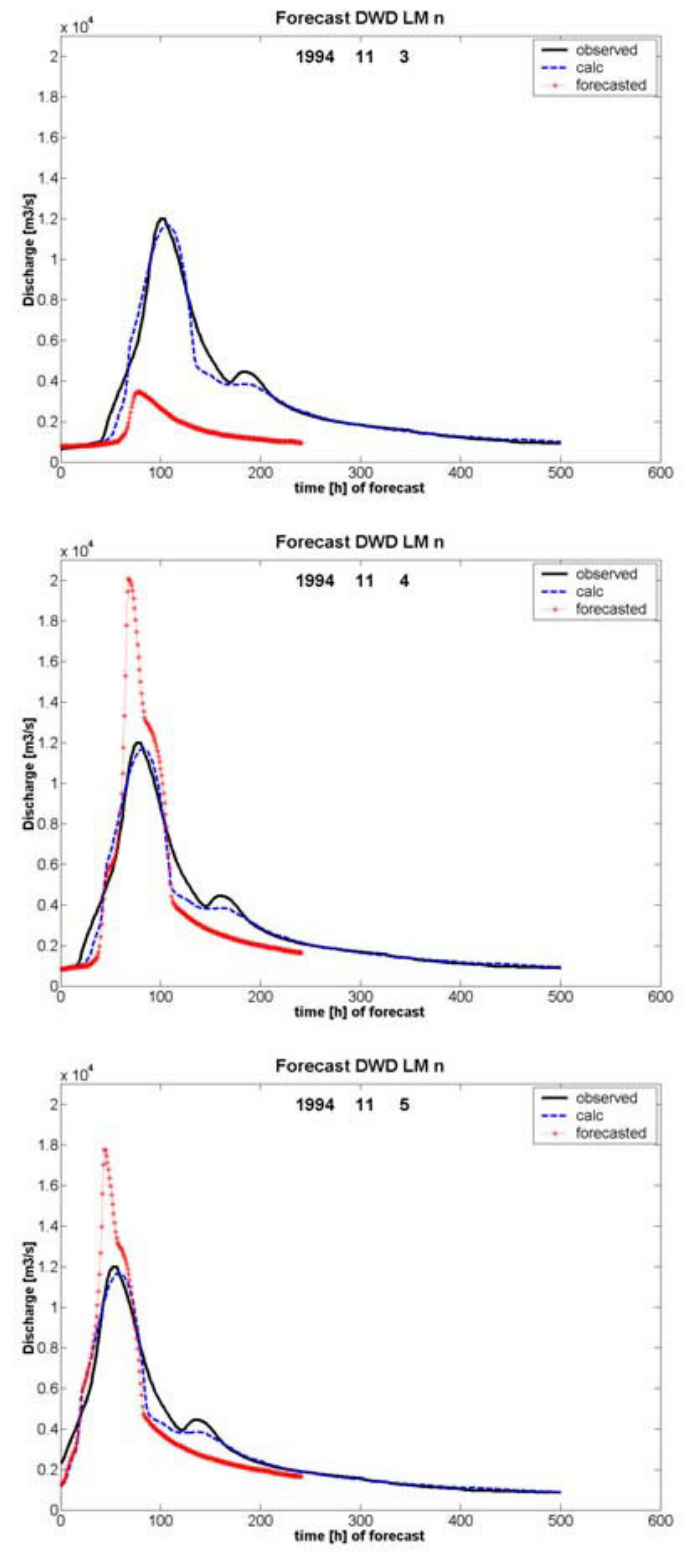

Fig. 9. Successive daily flood forecasts based upon the DWD LM deterministic hindcasts from 03.11.1994 to 05.11.1994

\section{Conclusions}

An introduction to the $5^{\text {th }}$ framework EU project European Flood Forecasting System (EFFS) is given. In this project the feasibility of an extension of flood forecasting / warning lag times up to 10 days - by employing a combination of advanced meteorological and hydrological models - is studied. Results of a coupled approach between numerical weather prediction systems and a rainfall-runoff model are presented for a case study on the river Po (northern Italy). Meteorological models with different spatial resolutions - in deterministic as well as in probabilistic ensemble forecasting mode - are coupled with the distributed physically-based hydrological model TOPKAPI that was adapted and calibrated at a $1 * 1 \mathrm{~km}$ resolution for the upper section of the river Po $\left(37.000 \mathrm{~km}^{2}\right)$.

In November 1994 severe weather conditions resulted in a 100-year flood in the river Po. Hydrological simulations using the meteorological hindcasts of this event showed positive results regarding the possible extension of the flood warning time. In this special historical case strong indications of an extraordinary flood - predictions with the right timing and $83 \%$ of the later observed discharge were obtained nine days ahead of the event. This was possible by coupling TOPKAPI with the deterministic hindcasts of the ECMWF (resolution $40 * 55 \mathrm{~km}$ ). However, the predictions oscillated widely and large differences in prediction skill between the several meteorological models were observed. The probabilistic ensemble prediction approach did not live up to expectation as the forecasts were negatively biased in time as well as in discharge magnitude. Concluding, it can be said that the results of this case study were encouraging, but that at the current state of the art only warnings and no deterministic quantitative flood forecasts are feasible for an extended time horizon. Further improvement of precipitation prediction skill on the meteorological side is needed and further work has to be done to tackle the uncertainty issue on the hydrological side.

\section{Acknowledgments}

This work was supported by the EC FP5 project European Flood Forecasting System, by the Marco Polo scholarship of the University of Bologna, and part of it was carried out at the Division of Engineering and Applied Sciences at Harvard University. Meteorological data were provided by the Region of Piedmont, the Swiss Met office, the Region of Val d'Aosta and the Autorità del bacino del fiume Po (ABP); hydrometric data were provided by the ABP.

\section{References}

Abbott, M., Bathurst, J.C., Cunge, J.A., O'Connell, P.E. and Rasmussen, J., 1986a. An introduction to the European Hydrological System - Système Hydrologique Européen, SHE; 1. History and philosophy of a physically based distributed modelling system. J. Hydrol., 87, 45-59.

Abbott, M., Bathurst, J.C., Cunge, J.A., O'Connell, P.E. and Rasmussen, J., 1986b. An introduction to the European Hydrological System - Système Hydrologique Européen, SHE; 2. Structure of a physically based, distributed modelling. $J$. Hydrol., 87, 79-102.

Abbott, M. Bathurst, J.C., Cunge, J.A., O'Connell, P.E. and Rasmussen, J., 1986c. Sensitivity analysis of the Système Hydrologique Européen for an upland catchment. J. Hydrol., 87, 103-123. 

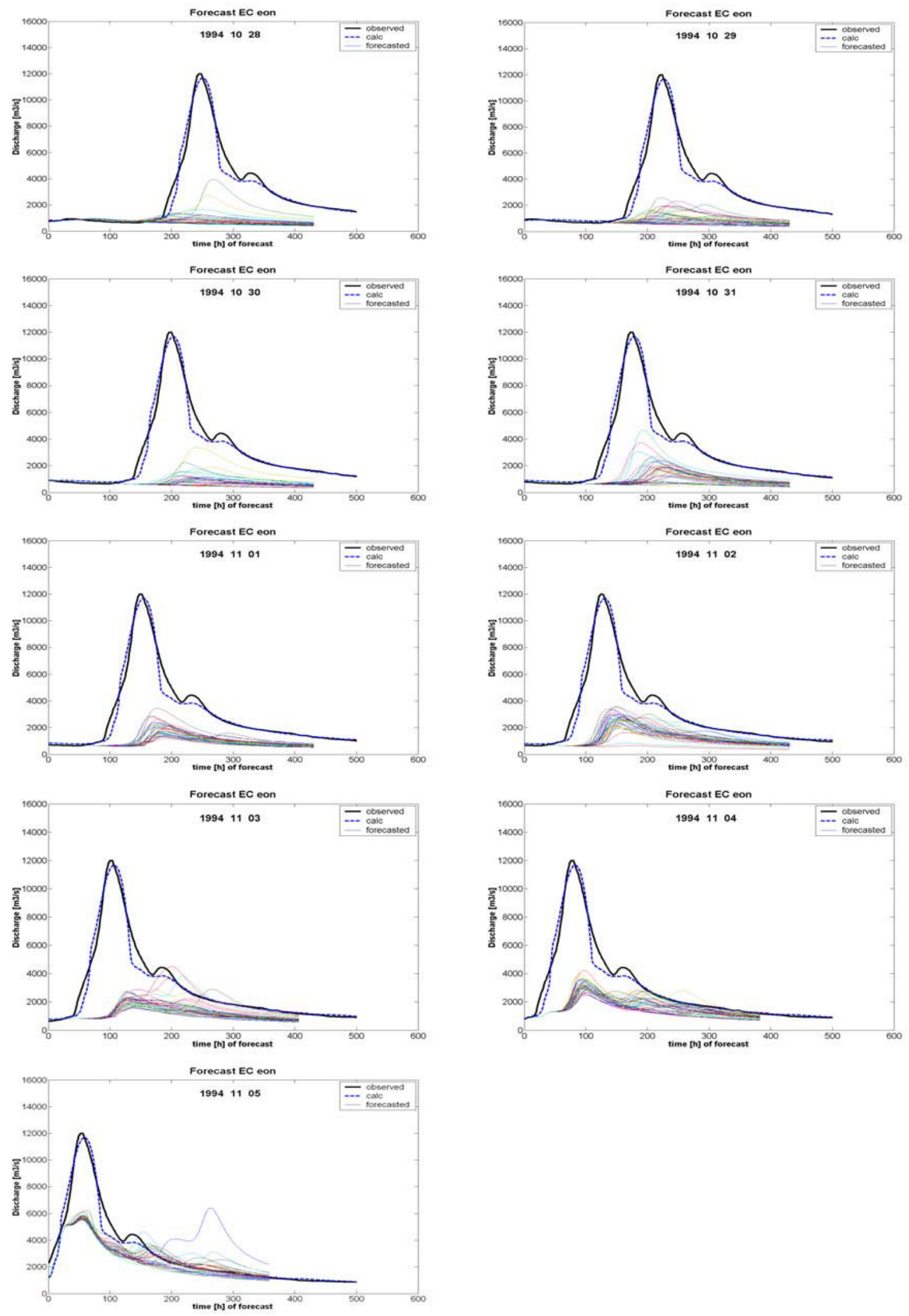

Fig. 10. Successive daily flood forecasts based upon the old ECMWF EPS probabilistic hindcasts from 28.10.1994 to 05.11.1994 
Jens Bartholmes and Ezio Todini
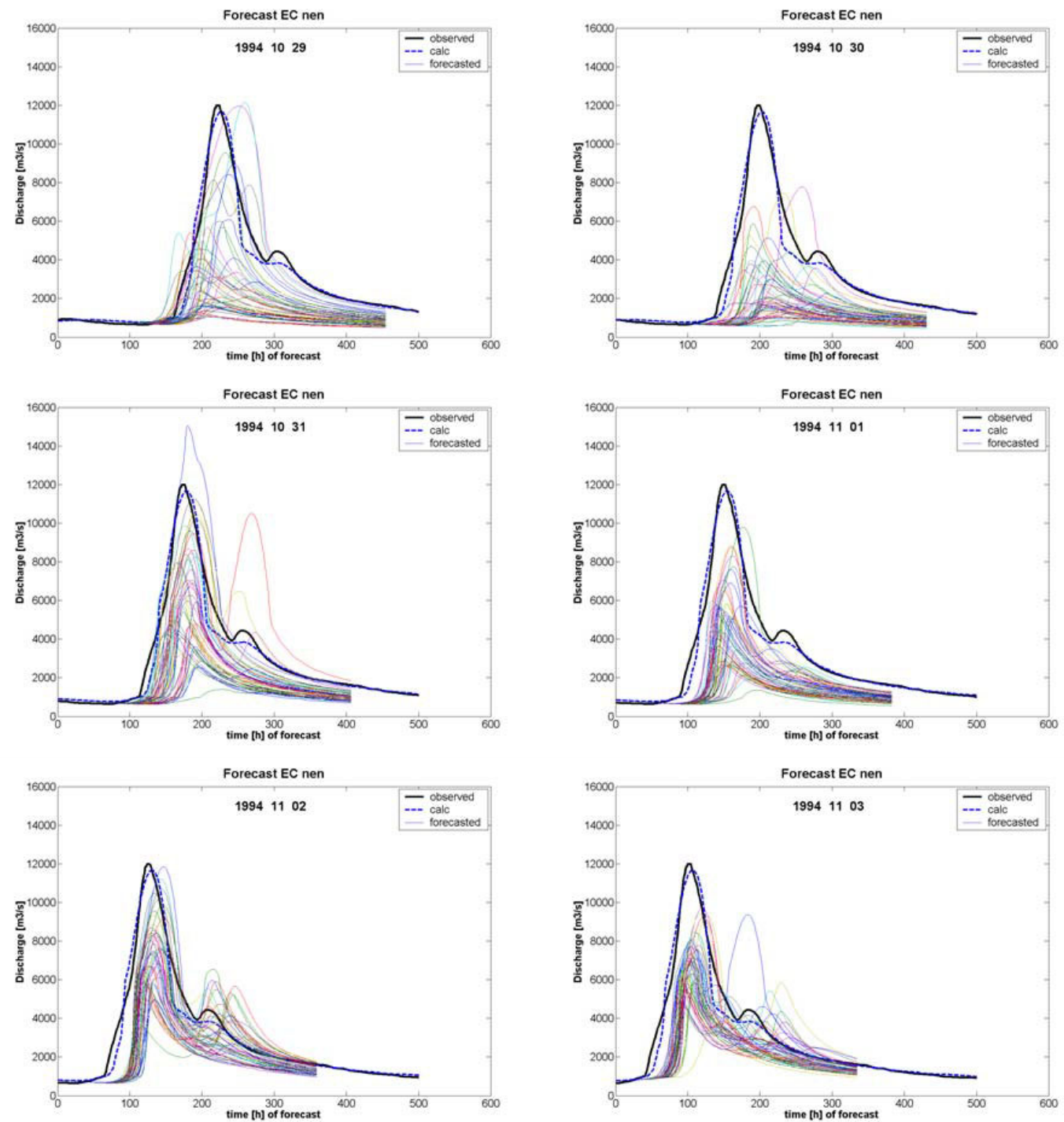

Fig. 11. Successive daily flood forecasts based upon the new ECMWF EPS probabilistic hindcasts from 29.10.1994 to 03.11.1994

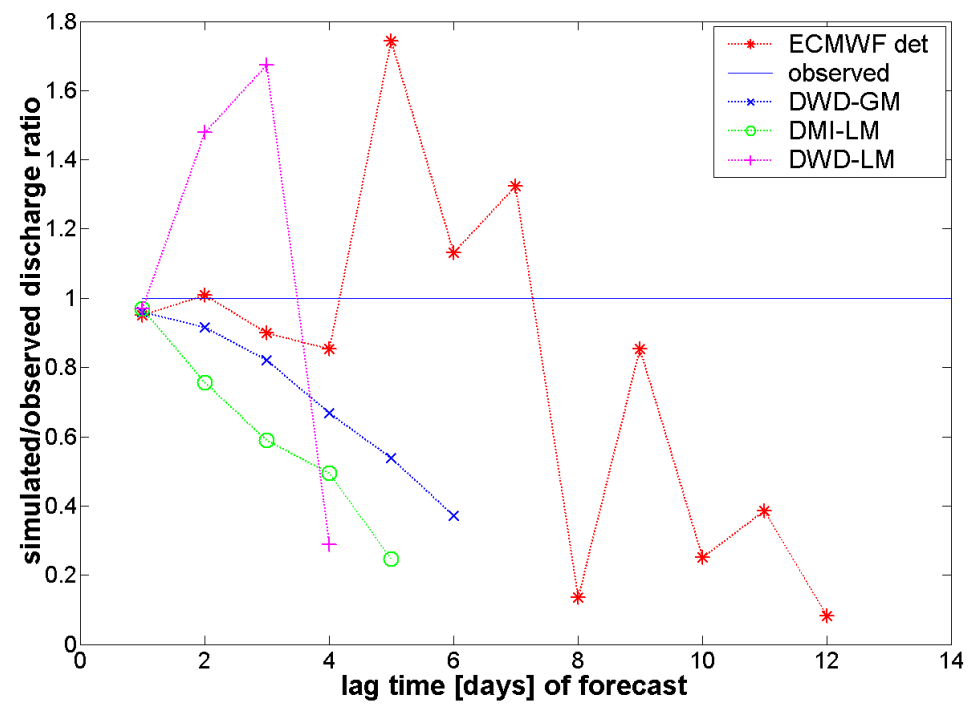

Fig. 12. Forecasting skill of the deterministic approach regarding peak discharge 


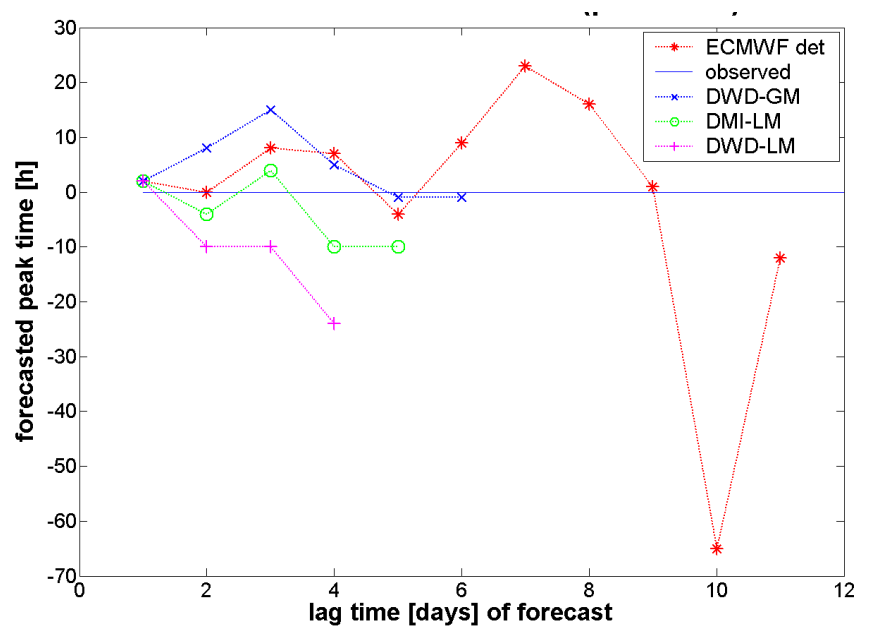

Fig. 13. Forecasting skill of the deterministic approach regarding peak time
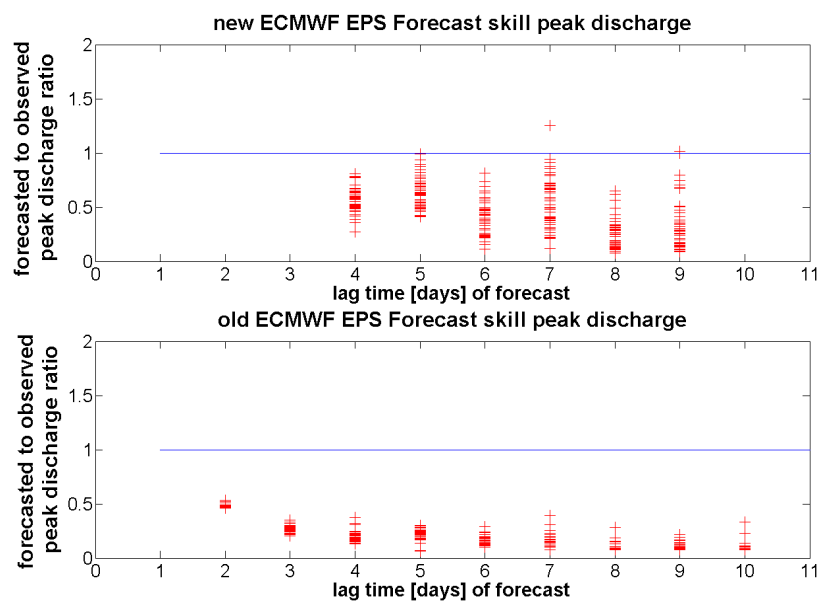

Fig. 14. Forecasting skill of the probabilistic approach regarding peak discharge
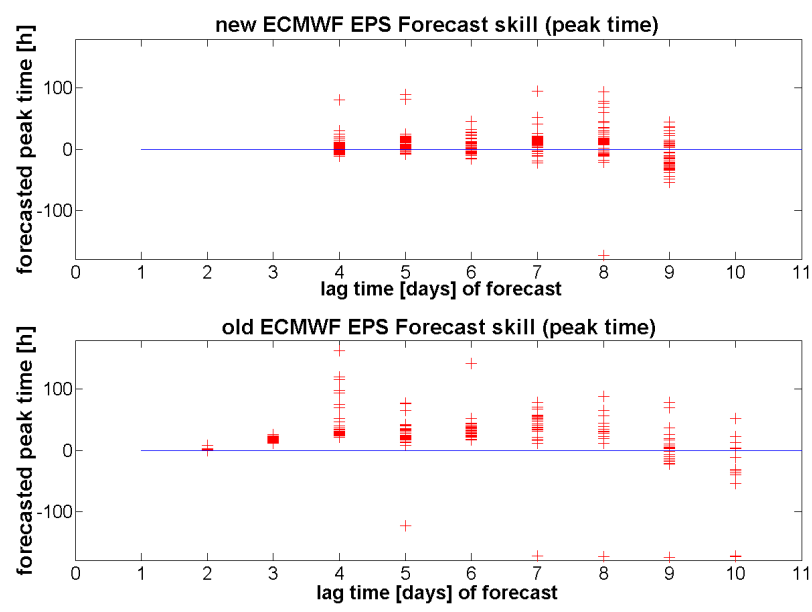

Fig. 15. Forecasting skill of the probabilistic approach regarding peak time

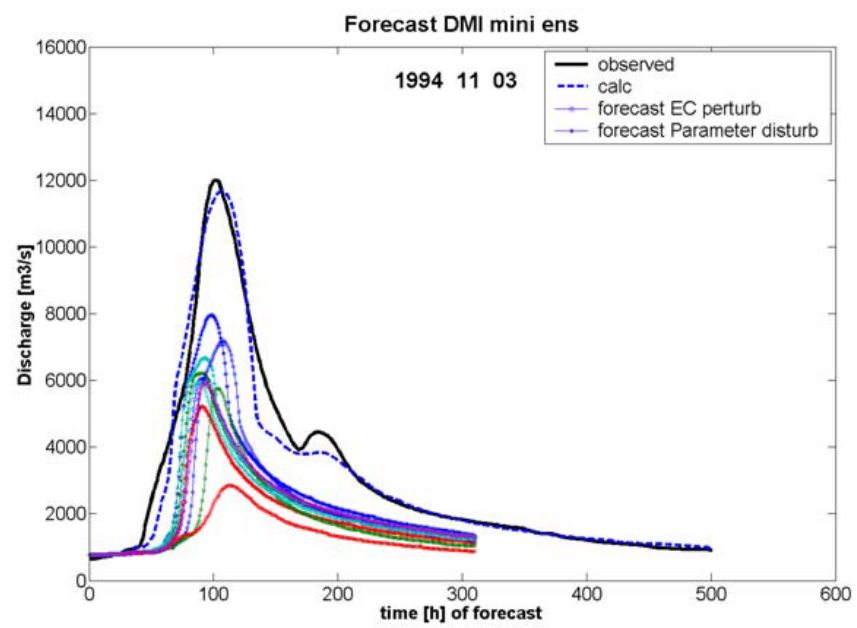

Fig. 16. Forecast based on the DMI LM mini ensemble hindcasts for the 03.11.1994

Table 1. Statistic values of both ECMWF EPS for predicted against observed peak discharges and differences in peak time between predicted and observed values

\begin{tabular}{|c|c|c|c|c|c|c|c|c|}
\hline \multirow[b]{2}{*}{ Lag time } & \multicolumn{2}{|c|}{ Old EPS mean } & \multicolumn{2}{|c|}{ New EPS mean } & \multicolumn{2}{|c|}{ Old EPS standard dev. } & \multicolumn{2}{|c|}{ New EPS standard dev. } \\
\hline & Peak \% & $\begin{array}{l}\text { Time } \\
\text { difference }\end{array}$ & Peak \% & $\begin{array}{l}\text { Time } \\
\text { difference }\end{array}$ & Peak \% & $\begin{array}{l}\text { Time } \\
\text { difference }\end{array}$ & Peak \% & $\begin{array}{l}\text { Time } \\
\text { difference }\end{array}$ \\
\hline 2 & 48 & 7.8 & & & 2 & 36.7 & & \\
\hline 3 & 27 & 18.5 & & & 3 & 4.2 & & \\
\hline 4 & 20 & 49.0 & 56 & 3.8 & 5 & 35.8 & 12 & 14.4 \\
\hline 5 & 22 & 24.9 & 63 & 10.5 & 5 & 31.5 & 14 & 17.5 \\
\hline 6 & 16 & 35.4 & 40 & 5.1 & 4 & 21.0 & 17 & 13.3 \\
\hline 7 & 15 & -2.4 & 53 & 10.1 & 7 & 93.0 & 24 & 18.4 \\
\hline 8 & 10 & -74.2 & 23 & 12.2 & 4 & 108.6 & 14 & 46.6 \\
\hline 9 & 11 & -42.3 & 33 & -9.1 & 4 & 87.2 & 23 & 23.6 \\
\hline 10 & 10 & -117.3 & & & 5 & 80.8 & & \\
\hline
\end{tabular}


Bartholmes, J., Todini, E., Barros, A. and Liu, Z., 2003. Operational flood forecasting in large catchments : Application of the Topkapi model to the river Po basin in Northern Italy. In Review. uropean Flood Forecasting System. Intl. J. River Basin Manage., 1, 49-59.

Bergstrom, S., 1976. Development and application of a conceptual runoff model for Scandinavian countries. SMHI report No.7, Norrkoping, Sweden.

Beven, K.J. and Kirkby, M.J., 1979. A physically based, variable contributing area model of basin hydrology. Hydrolog. Sci. Bull., 24, 1-3.

Bindlish, R. and Barros, A.P., 2000. Disaggregation of rainfall for one-way coupling of atmospheric and hydrological models in regions of complex terrain. Global Planet. Change, 25, 111132

Brath, A., 1995. Hydrometeorological aspects of the 1994 flooding in the upper Po river basin. U.S.-Italy Research workshop on the Hydrometeorology, impacts, and management of extreme floods, Perugi, Italy.

Buizza, R. and Palmer, T.N., 1995. The singular vector structure of the atmospheric general circulation. J. Atmos. Sci., 52 , 14341456

Buzzi, A., Tartaglione, N., Cacciamani, C., Paccagnella, T. and Patruno, P., 1995. The Piedmont flood of November 1994: Preliminary meteorological analysis. MAP Newsletter 2, 2-6.

Cassardo, C., Loglisci, N., Gandini, D., Qian, M.W., Niu, G.Y., Ramieri, P., Pelosini, R. and Longhetto, A., 2002. The flood of November 1994 in Piedmont, Italy : a quantitative analysis and simulation. Hydrol. Process., 16, 1275-1299.

Chiew, F. and McMahon, T., 1994. Application of the daily rainfallrunoff model MODHYDROLOG to 28 Australian catchments. J. Hydrol., 153, 383-416.

Chow, V.T., Maidment, D.R. and Mays, L.W., 1988. Applied Hydrology. McGraw-Hill Book Company, New York, USA

Dingman, S.L., 2002. Physical Hydrology. Prentice Hall, NJ, USA.

Doorenbos, J., Pruitt, W.O., Aboukhaled, A., Damagnez, J., Dastane, N.G., van den Berg, C., Rijtema, P.E., Ashford, O.M. and Frere, M., 1984. Guidelines for predicting crop water requirements. FAO Irrig. Drainage Pap., 24, Rome, Italy.

Dunne, T., 1978. Field studies of hillslope flow process. In: Hillslope Hydrology, M.J. Kirkby (Ed.), Wiley, Chichester, UK. 227-293

Feldman, A.D., 1981. HEC models for water resources systems simulations : theory and experience. Adv. Hydrosci.,12, $297-$ 423

Franchini, M., Wendling, J., Obled, C. and Todini, E., 1996. Physical interpretation and sensitivity analysis of the TOPMODEL. J. Hydrol., 175, 293-338.

Heise, E., Damrath, U., Doms, G., Fruehwald, D., Richter, B. and Steppeler, J., 2000. Operational quantitative precipitation forecasting at the German Weather Service. J. Hydrol., 239, 260-285.

Kaellen, E., 1996. HIRLAM Documentation manual. SMHI, Norrkoepping, Sweden

Liu, Z., 2002. Toward A Comprehensive Distributed/Lumped Rainfall-Runoff Model: Analysis of Available Physically-Based Models and Proposal of a New TOPKAPI Model. PhD dissertation, University of Bologna, Italy.

Liu, Z. and Todini, E., 2002. Towards a comprehensive physicallybased rainfall-runoff model. Hydrol. Earth Syst. Sci., 6, 85988.

Luino, F., 1999. The flood and landslide event of November 4-6 1994 in Piedmont Region. Phys. Chem. Earth (A), 24, 123129.
Molteni, F., Buizza, R., Palmer, T.N. and Petroliagis, T., 1996. The new ECMWF Ensemble Prediction System : Methodology and Validation. Quart. J. Roy. Meteorol. Soc., 122, 73-119.

Nash, J.E. and Sutcliffe, J.V., 1970. River flow forecasting through conceptual models I: A discussion of principles. J. Hydrol., 10, 282-290.

Sattler, K., 2002. Precipitation hindcasts of historical flood events. DMI scientific report 02-13, Copenhagen, Denmark. ISBN $87-$ 7478-467-6

Sattler, K. and Feddersen, H., 2003. Study on the treatment of uncertainties in limited area NWP rainfall using different ensemble approaches. Scientific report for EFFS project. Downloadable from http://effs.wldelft.nl

Singh, V.P., 2002 . Mathematical modelling of watershed hydrology. J. Hydrol. Eng., 7, 270-292.

Todini, E., 1995. New trends in modelling soil processes from hill-slope to GCMS Scales. In: The role of water and the hydrological cycle in global change, H.R. and S.A. Oliver, (Eds.), NATO ASI Series I: Global Environmental Change, 31, 317-347.

Todini, E., 1996. The ARNO rainfall-runoff model. J. Hydrol., 175, 339-382.

Todini, E. and Ciarapica, L., 2001. The TOPKAPI model. In: Mathematical Models of Large Watershed Hydrology (Chapter 12), V.P. Singh et al. (Eds.), Water Resources Publications, Littleton, Co, USA.

Willmott, C.J., 1981. On the validation of models. Phys. Geogr., 2, 184-194.

Zhao, R.J. and Liu, X.R., 1995. The Xinanjang model. In: Computer models of watershed hydrology, V.P. Singh et al. (Eds.), Water Resources Publications, Littleton, Co, USA.

\section{Appendix A}

To evaluate model performance in a statistically meaningful way the following four skill factors were chosen :

Nash Sutcliffe $=1-\left(\frac{\sum(\operatorname{sim}-o b s)^{2}}{\sum\left(o b s-\text { mean }_{o b s}\right)^{2}}\right)$

(Nash and Sutcliffe, 1970)

Volume control $=1-a b s\left(\frac{\sum \operatorname{sim}}{\sum o b s}-\frac{\sum o b s}{\sum s i m}\right)$
Chiew and McMahon $=1-\left(\frac{\sum(\sqrt{\text { sim }}-\sqrt{o b s})^{2}}{\sum\left(\sqrt{o b s}-\sqrt{\text { mean }_{\text {obs }}}\right)^{2}}\right)$
(Chiew, 1994)

$$
\begin{aligned}
& \text { Willmott }= \\
& 1-\frac{\sum(\operatorname{sim}-o b s)^{2}}{\sum\left(a b s\left(\operatorname{sim}-\text { mean }_{o b s}\right)+a b s\left(o b s-\text { mean }_{o b s}\right)\right)^{2}}
\end{aligned}
$$

(Willmott, 1981) 